\title{
PEMANFAATAN RUMPUT LAUT COKLAT SEBAGAI BAHAN TAMBAHAN PEMBUAATAN PELET PAKAN IKAN
}

\author{
Sutrisno \\ Prodi Teknik Industri, Fakultas Teknik Industri, \\ UPN "Veteran" Yogyakarta \\ Jl. Babarsari 2 Tambakbayan Yogyakarta 55281 \\ e-mail : trisno_upnvy@yahoo.co.id
}

\begin{abstract}
ABSTRAK
Pengabdian masyarakat ini dilakukan di Kelompok Ternak Ikan Mina Tirto Dusun Tirto Desa Triharjo Kecamatan Pandak Kabupaten Bantul. Pengabdian dilakukan dengan memberi pelatihan pada kelompok ternak ikan tentang cara membuat pelet pakan ikan alternatif secara fermentasi menggunakan bioaktivator buatan sendiri dengan bahan tambahan rumput laut coklat.

Rumput laut coklat tersebut dapat berfungsi sebagai bender (bahan perekat) dalam pembuatan pelet ikan. Bender atau bahan perekat adalah bahan tambahan yang digunakan untuk menyatukan semua bahan baku dalam pembuatan pelet pakan ikan. Bahan tambahan yang digunakan sebagai perekat sangat menentukan stabilitas pakan dalam air (Meyer dan Eldin, 1972).

Stabilitas pelet dalam air akan menyebabkan pelet menjadi mengambang lebih lama di air. Selain berfungsi sebagai bahan perekat sehingga dapat menyebabkan pelet mengambang di air, rumput laut coklat juga mengandung nutrisi yang dibutuhkan oleh ikan dalam pertumbuhannya. Setelah dilakukan pelatihan dan diujicobakan sebagai pakan ikan maka pelet pakan ikan alternatif yang dihasilkan dengan tambahan rumput laut coklat didalamnya dapat mengambang di air dan lebih mempercepat pertumbuhan ikan.
\end{abstract}

Kata Kunci : pelet ikan alternatif, rumput laut coklat, bioaktivator

\section{PENDAHULUAN}

Dusun Tirto Desa Triharjo Kecamatan Pandak Kabupaten Bantul DIY terletak di sebelah selatan Kabupaten Bantul, kurang lebih $10 \mathrm{Km}$. Berdasarkan profil tata ruang Kabupaten Bantul, Desa Triharjo adalah termasuk kawasan jalur hijau yang terletak di dekat pesisir pantai. Lahan yang subur dan irigasi yang baik merupakan salah satu faktor yang menyebabkan sebagian masyarakat mengandalkan pertanian sebagai sabagai salah satu mata pencaharian. Irigasi yang baik telah memperlancar usaha pertanian masyarakat Desa Triharjo, jika mereka menanam padi maka panen dapat mereka lakukan sebanyak tiga kali dalam satu tahun.

Irigasi yang baik mendorong masyarakat Triharjo untuk membuka usaha tambahan dengan budidaya ikan, tidak terkecuali di Dusun Tirto. Budidaya ikan sudah mulai dirintis sejak tahun 2009 adapun ikan yang di budidayakan kebanyakan adalah ikan lele dan nila. Budidaya ikan lele dan nila terebut mereka lakukan secara berkelompok maupun secara sendiri- sendiri. Masyarakat senang membudidayakan ikan lele dan nila karena lebih cepat masa panennya dibandingkan dengan ikan yang lain. Masa panen lele konsumsi adalah \pm 2 bulan dari bibit ukuran 5- $7 \mathrm{~cm}$, sedangkan masa panen ikan nila adalah \pm 3 bulan dari bibit ukuran 5-7 cm. Di Dusun Tirto Desa Triharjo saat ini ada 5 kelompok budidaya ikan yang rata-rata perkelompok terdiri dari 15 - 20 anggota. Adapun kolam sebagai tempat budidaya mereka sewa dari tanah kas desa. Masing-masing anggota rata-rata mempunyai kolam seluas $60-80 \mathrm{~m}^{2}$ yang digunakan untuk memelihara 7 ribu -10 ribu ekor lele.

Kolam kelompok yang dijadikan obyek pengabdian bagi masyarakat ini adalah kelompok ternak ikan "Mina Tirto" yang ada di Dusun Tirto Triharjo Pandak Bantul DIY. Kolam kelompok ini telah mempunyai kepengurusan dalam pengelolaannya. Berdasarkan wawancara awal dengan pengurus dan anggota kelompok diperoleh informasi bahwa kelompok ternak ikan "Mina Tirto" ingin memanfaatkan rumput laut coklat yang banyak terdapat di pesisir pantai selatan sebagai bahan 
tambahan dalam pembuatan pelet pakan ikan. Saat ini rumput laut coklat yang banyak terdapat di pesisir pantai selatan yang terletak di dekat Desa Triharjo belum dimanfaatkan secara optimal, padahal berdasarkan penelitian yang sudah dilakukan rumput laut coklat dapat digunakan sebagai bender atau bahan perekat yang merupakan bahan tambahan yang dapat digunakan untuk menyatukan semua bahan baku dalam pembuatan pakan ikan. Bahan tambahan yang digunakan sebagai perekat sangat menentukan stabilitas pakan dalam air, sehingga dapat membuat pelet ikan yang dihasilkan mengambang di air. Tepung rumput laut coklat dapat menjadi bahan

Pakan merupakan komponen penting dalam usaha budidaya ikan. Ikan lele dan nila memerlukan pakan yang berprotein tinggi dan jumlah yang banyak. Harga pakan (pelet) dipasaran relatif mahal, yaitu $\mathrm{Rp}$ $9,500 / \mathrm{Kg}$. Untuk mencapai lele dan nila konsumsi (1 $\mathrm{kg}$ berisi 8-9 ekor lele) dibutuhkan waktu sekitar dua bulan dan tiga dengan kebutuhan pakan $1 \mathrm{~kg} / 1 \mathrm{~kg}$. Tingginya harga dan banyaknya jumlah pakan tersebut menyebabkan biaya produksi menjadi tinggi sehingga keuntungan yang didapatkan petani relatif sedikit karena harga jual lele konsumsi kepada pengepul rata-rata adalah Rp 13.000 - Rp. 14000/ kg dan nila rata-rata $\mathrm{Rp} 19.000-20.000 / \mathrm{kg}$.

Untuk menanggulangi mahalnya harga pakan di pasaran maka kelompok teknak ikan "Mina Tirto" ingin membuat pelet pakan ikan sendiri dengan memanfaatkan rumput laut

Pengabdian kepada masyarakat ini bertujuan untuk memberikan pelatihan cara pembuatan pelet ikan alternatif secara

\section{METODE PENELITIAN}

Pelet alternative pengganti pelet buatan pabrik dapat dibuat dari berbagai bahan. Kandungan utama pelet yang paling dominan adalah tepung ikan. Tepung ikan digunakan karena kandungan proteinnya yang tinggi dan gizi lainnya. Harga dari tepung ikan mahal, oleh karena itu kita dapat mencampurnya dengan bahan-bahan lain yang lebih murah tanpa mengurangi kandungan protein yang ada. perekat karena rumput laut mengandung senyawa hidrokoloid. Senyawa hidrokoloid sangat diperlukan keberadaannya dalam suatu produk karena berfungsi sebagai pembentuk gel, penstabil, pengemulsi, dan pensuspensi. Selain sebagai bahan perekat, rumput laut coklat juga mengandung nutrisi yang dapat mempercepat pertumbuhan ikan. Berdasarkan wawancara awal yang sudah dilakukan, pengurus dan anggota kelompok juga sangat mengharapkan sekali adanya mitra pendamping yang dapat memberikan pelatihan untuk pembuatan pelet pakan ikan dengan memanfaatkan rumput laut coklat yang banyak tersedia sebagai bahan tambahannya..

coklat yang banyak tersedia di Desa Triharjo sebagai bahan tambahan, karena berdasarkan informasi yang berkembang rumput laut coklat dapat digunakan sebagai bahan tambahan dalam pembuatan pelet pakan lele. Permasalahan yang timbul adalah kelompok ternak ikan "Mina Tirto" belum mempunyai pengetahuan dan cara untuk memanfaatkan rumput laut coklat sebagai bahan tambahan dalam pembuatan pelet pakan ikan.

Berdasarkan hal tersebut maka permasalahan dalam pengabdian ini adalah bagaimana memberikan pelatihan pembuatan pelet ikan alternatif secara fermentasi dengan tambahan rumput laut coklat kepada kelompok ternak ikan "Mina Tirto". Pelatihan pembuatan pelet ikan alternatif dilakukan untuk mensubstitusi pakan buatan pabrik yang berharga mahal dan memberatkan peternak.

fermentasi dengan tambahan rumput laut coklat kepada kelompok ternak ikan "Mina Tirto".

Pakan alternative yang dibuat harus disesuaikan dengan kebutuhan standar ikan untuk tumbuh dan berkembang dengan baik dan cepat. Terdapat banyak bahan alternative yang dapat digunakan, dimana penggunaan bahan alternative tersebut yang menjadi acuannya adalah kandungan proteinnya. Berikut adalah tabel berbagai bahan beserta kandungannya dalam satuan persen (\%). 
Tabel 1. Kandungan Protein dan Lemak dari berbagai bahan alternative

\begin{tabular}{|l|c|c|}
\hline \multicolumn{1}{|c|}{ Bahan } & Kandungan Protein & Kandungan Lemak \\
\hline Tepung ikan & 62,99 & 8,4 \\
\hline Tepung kedelai & 36,6 & 14,3 \\
\hline Bungkil kelapa & 18,46 & 15,73 \\
\hline Tepung jagung & 10,4 & 0,53 \\
\hline Dedak halus & 15,58 & 6,8 \\
\hline Tepung tapioca & 2,6 & 2,6 \\
\hline
\end{tabular}

Misalnya akan dibuat pelet dari campuran $10 \mathrm{~kg}$ tepung ikan (kandungan protein 62,9\%), $20 \mathrm{~kg}$ tepung kedelai (kandungan protein $36,6 \%$ ), dan $20 \mathrm{~kg}$ dedak halus (kandungan protein 15,58\%). Untuk mengetahui apakah campuran tersebut memenuhi kebutuhan protein ikan dapat dihitung sebagai berikut: jumlah protein dalam tepung ikan $=62,9 \% \times 10 \mathrm{~kg}=6,299$ $\mathrm{kg}$, jumlah protein dalam dedak tepung kedelai $=36,6 \%$ x $20 \mathrm{~kg}=7,32 \mathrm{~kg}$, jumlah

Pembuatan bioaktivator menggunakan cairan empedu sapi, Bioaktivator yang digunakan sebagai campuran dalam pembuatan pelet ikan alternatif dengan cara fermentasi dibuat secara mandiri. Bioaktivator tersebut dibuat dengan cara memfermentasi cairan empedu sapi, leri, tetes dan air kelapa serta air sebagai pengencer. Penambahan bioaktivator dapat mempercepat pertumbuhan ikan. Selain itu tingkat kematian ikan juga kecil serta daging ikan yang dipanennya menjadi lebih padat. Dengan bioaktivator bisa mendapatkan hasil panen dengan kualitas yang baik. Hal ini di indikasikan dengan pertumbuhan ikan lebih

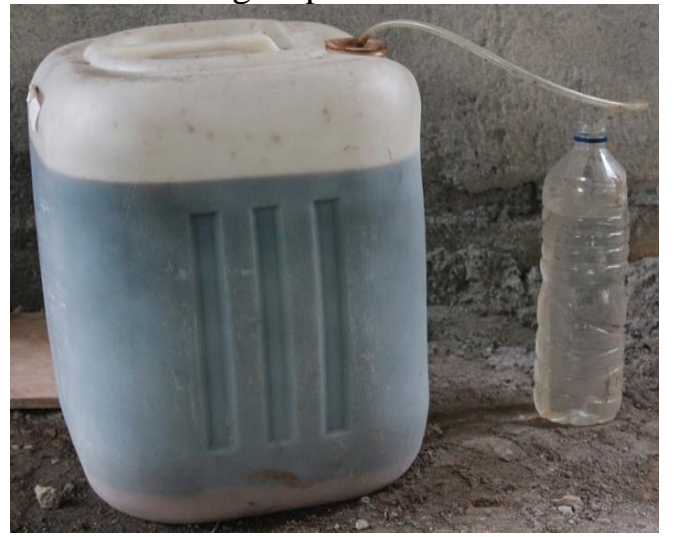

Gb.1. Proses fermentasi tetes tebu dan cairan empedu sapi

Cara kerja pembuatan bioaktivator dari cairan empedu sapi:

a. Siapkan ember dengan volume 10 liter protein dalam dedak halus $=15,58 \%$ x $20 \mathrm{~kg}$ $=3,116 \mathrm{~kg}$. Total protein yang didapatkan dari campuran $10 \mathrm{~kg}$ tepung ikan, $20 \mathrm{~kg}$ tepung kedelai, dan $20 \mathrm{~kg}$ dedak halus adalah $16,735 \mathrm{~kg}$. Artinya dari total berat bahan baku $50 \mathrm{~kg}$ didapat protein $16,735 \mathrm{~kg}$ atau $33,47 \%$ dari adonan tersebut adalah protein. Hal ini memenuhi standar untuk digunakan sebagai pakan ikan, dimana minimal ketersediaan kandungan protein kasarnya adalah sebanyak $30 \%$.

cepat sehingga dapat segera dipanen, ukuran ikan seragam, dan tidak bau lumpur atau tanah.

Prinsip dasar dari pembuatan bioaktivator ini adalah dengan mengembangbiakkan mikroba menggunakan cairan empedu sapi. Proses pembuatannya dilakukan dengan mencampurkan cairan empedu sapi yang banyak mengandung mikroba pengurai, leri yang kaya karbohidrat, tetes, dan air kelapa yang banyak mengandung glukosa dicampur dan ditambah air kemudian difermentasi selama 21 hari.( Djuarnani, 2008)

b. Isilah ember dengan air sebanyak 5 liter

c. Tambahkan cairan enpedu sapi sebanyak $30 \mathrm{ml}$ dan tetes tebu sebanyak 1 liter

d. Tambahkan 1 liter air kelapa dan 30 gram tepung beras

e. Tambahkan air sampai volume 8 liter

f. Aduk sampai merata dengan menggunakan batang pengaduk

g. Masukkan kedalam jerigen dan ditutup

h. Tunggu proses fermentasi berjalan sampai 21 hari

i. Selama proses fermentasi berlangsung usahakan gas yang terjadi bisa keluar dengan tanpa udara luar bisa masuk.

j. Setelah 21 hari tutup jerigen dibuka, bioaktivator yang baik ditandai dengan bau segar seperti bau tape dan warna larutan hitam kecoklatan. 
1. Cara pembuatan pelet ikan alternatif secara fermentasi dengan tambahan

Pembuatan pelet ikan alternatif ini dilakukan dengan menambahkan bulu ayam dan rumput laut coklat sebagai bahan agar pelet yang dihasilkan dapat mengambang di air. Selain itu bulu ayam dan rumput laut coklat juga banyak mengandung protein yang dapat mempercepat pertumbuhan ikan.

Prinsip dasar dari fermentasi bulu ayam dan rumput laut coklat menggunakan bioaktivator dari cairan empedu sapi yang dibuat sendiri ini adalah mencampur bulu ayam, rumput laut coklat, tepung ikan, tepung kedelai, dan dedak halus kemudian dimasukkan dalam drum dimana drum tersebut dibuat lubang dibagian tutupnya agar gas yang ditimbulkan bisa keluar, namun tidak ada udara luar yang masuk dalam drum. Proses fermentasi dilakukan selama 30 hari. Gambar proses fermentasi dapat dilihat pada gambar dibawah ini.

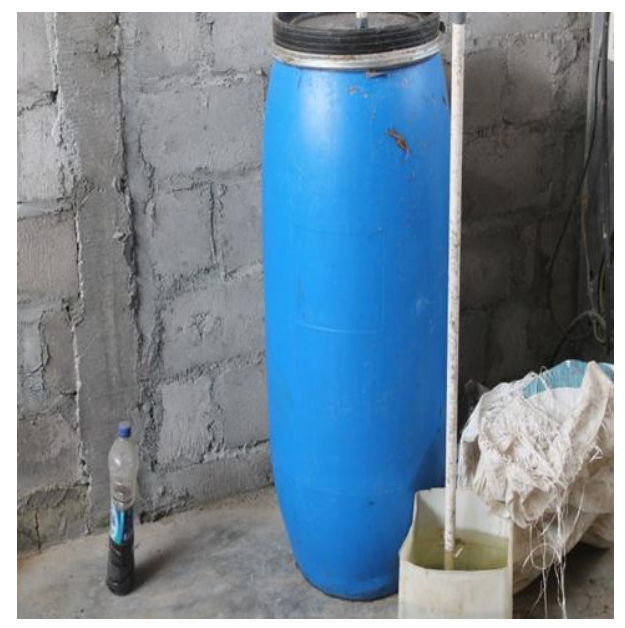

Gambar 2. Proses fermentasi bulu ayam dengan bioaktivator dari cairan empedu sapi

Cara kerja pembuatan pelet ikan alternatif secara fermentasi adalah sebagai berikut:

a. Siapkan drum dengan volume 200 liter

b. Campurkan $2 \mathrm{~kg}$ bulu ayam, $2 \mathrm{~kg}$ rumput laut coklat, $10 \mathrm{~kg}$ tepung ikan, $20 \mathrm{~kg}$ tepung kedelai, dan $20 \mathrm{~kg}$ dedak halus

c. Siramlah dengan 2 lt bioaktivator yang dibuat sendiri menggunakan cairan empedu sapi, yang telah diencerkan dengan air sampai basah rumput laut coklat

d. Masukan campuran bulu ayam, rumput laut coklat, tepung ikan, tepung kedelai, dan dedak halus tersebut ke dalam drum dan ditutup rapat.

e. Tunggu proses fermentasi berjalan sampai 30 hari

f. Selama proses fermentasi berlangsung usahakan gas yang terjadi bisa keluar dengan tanpa udara luar bisa masuk.

g. Setelah 30 hari tutup drum dibuka, ambilah campuran pelet ikan tersebut dan tiriskan.

h. Bahan-bahan campuran dalam pembuatan pakan ikan telah terfermentasi dengan baik dan mempunyai kandungan protein yang tinggi, yaitu kandungan proteinnya berada di atas batas minimal kandungan protein dari suatu pakan ikan.

\section{ANALISA DAN PEMBAHASAN}

Bahan yang digunakan untuk membuat bioaktivator sebagai campuran pembuatan pelet ikan alternatif secara fermentasi adalah bahan yang murah dan mudah didapat. Bioaktivator tersebut dibuat dari bahan utama yaitu cairan empedu sapi. Cairan empedu sapi di dapat dari Desa Segoroyoso, Pleret Bantul dimana desa ini sebagai central penyembelihan sapi di daerah Yogyakarta. Saat ini empedu sapi yang di hasilkan di Desa Segoroyoso perharinya kurang lebih 80-100 empedu, dan hanya dibuang sebagai limbah. Berdasarkan penelitian yang telah kami lakukan cairan dalam 1 empedu sapi dewasa rata-rata volumenya 25-35 ml. Setiap $25 \mathrm{ml}$ cairan empedu sapi ini mampu untuk membuat bioaktivator sebanyak 8 liter.

Pembuatan pelet pakan ikan secara fermentasi dengan campuran bulu ayam, rumput laut coklat, tepung ikan, tepung kedelai, dan dedak halus telah menghasilkan pelet yang tidak kalah kualitasnya jika dibandingkan dengan pelet buatan pabrik. Pelet alternatif yang dihasilkan dapat mengambang dan mempunyai kandungan nutrisi yang memenuhi standar pakan ikan yang baik, hal tersebut ditunjukkan dengan kandungan protein pakan yang berada di atas sarat minimal kandungan protein dalam suatu pakan ikan. 


\section{KESIMPULAN}

Pelet ikan alternatif yang dihasilkan merupakan pelet ikan hasil fermentasi dengan mencampurkan bulu ayam, rumput laut coklat, tepung ikan, tepung kedelai, dan dedak halus. Pelet ikan alternatif yang dihasilkan dapat mengambang di air dan mempunyai kandungan nutrisi sesuai standar pakan ikan sehingga dapat menggantikan pakan ikan buatan pabrik yang mahal harganya.

\section{DAFTAR PUSTAKA}

Meyer, Eldin. 1972. Bahan Perekat dalam Pembuatan Pakan Ikan. Jakarta: Agro Media Pustaka.

Djuarnani, N. 2008. Cara Membuat Bioaktivator. Yogyakarta: Agro Media. 